\title{
An Eco-criticism Reading of The Call of the Wild
}

\author{
GAO Wen-ting, LIU Jin-xia \\ Linyi University, Linyi, China
}

\begin{abstract}
This thesis first elaborates on the definition and causes of eco-criticism, then it expounds the formation of Jack London's eco-critical ideas. Based on these, the author attempts to analyze one of Jack London's masterpieces The Call of the Wild from the opinion of eco-criticism. The main purpose of this thesis is to dissect Jack London's ecological ideas by the analysis of the novel.
\end{abstract}

Keywords: eco-criticism, civilization, nature

\section{Introduction}

Since scholars have shown their great interests in London’s writings, a majority of them studied about London's writing style from traditional study perspectives. Most of their studies are discussions about Romanticism, Naturalism and Realism in London's works. By consulting CNKI (China National Knowledge Infrastructure) net, the writer found that there were 1,901 articles about Jack London. About 83\% of these articles researched romantic and naturalistic elements in London’s writings. While only 317 articles analyzed London’s works from ecological perspective. And furthermore, the amount of articles from eco-critical perspective is very few.

Literary researches in Romantic and Realistic perspectives only pay attention to London's writing style and objectives. Naturalistic researches are focused on the animals, plants, and other non-human creatures in the nature. Researches from ecological perspective are mainly about environmental problems revealed in London's writings. While eco-critical researches are related to both nature and human beings. This paper is not only a discussion about Jack London's writing style; it also interprets the relationship between nature and human from ecological perspective. So this thesis is of great meaning for people to consider and solve current problems they are facing.

\section{General Survey of Eco-criticism}

\section{The Definition of Eco-criticism}

William Rueckert has been the first man who used the term "eco-criticism" (Barry, 2009, p. 240). In 1978, he advocated "the application of ecology and ecological concepts to the study of literature" (Glotfelty \& Fromm, 1996, p. 107). Eco-criticism is the study of literature and environment from an interdisciplinary point of view where literature scholars analyze the environment and discuss possible solutions for the improvement of the contemporary environmental condition and examine the different ways literature treats the subject of nature.

GAO Wen-ting, B.D, Foreign Language School, Linyi University.

LIU Jin-xia, professor, M.A., Foreign Language School, Linyi University. 
Glotfelty's definition in The Ecocriticism Reader is that eco-criticism is "the study of the relationship between literature and the physical environment” (Glotfelty \& Fromm, 1996, p. 18). Lawrence Buell defines eco-criticism as "a study of the relationship between literature and the environment conducted in a spirit of commitment to environmentalist praxis” (Buell, 2001, p. 20).

Eco-critics examine human's perception of wilderness, and how it has changed in history and whether or not current environmental problems are accurately represented or even mentioned in popular culture and modern literature. Other disciplines, such as history, economics, psychology, philosophy, and biology are also considered by eco-critics to be possible or potential contributors to eco-criticism.

According to the author's understanding, eco-criticism is a study focusing on the relationship between human and nature. It not only pays attention to nature's current state, but also to human's development in different ages they live in. The idea of eco-criticism applied in literary critics plays an important role in the process of human's exploration of finding the balance between human and nature.

\section{Reasons for the Emergence of Eco-criticism}

Ecological crisis has become a global problem. The increasingly serious crisis which mainly manifested in the destruction of ecological balance and damage of environment triggered unprecedented attention to environment.

American Professor at Harvard University predicted that "if the main problem in 20th century is the race, then the most pressing problem in the 21st century is the global environment” (WEI, 2002, p. 35). Since the 1960s, people who realized the fact of constantly worsening ecological crisis and the importance of taking measures to protect the environment were forced to think about the relationship between nature and human beings. Ecological thinking has become a popular tendency, covering all fields of the society. Nearly all liberal arts have a cross-discipline with ecology, such as eco-criticism, eco-philosophy, ecological ethics, eco-politics, eco-socialism, eco-sociology, ecological anthropology, ecological psychology, eco-literature, ecological art, and ecological economics. With the limitation of insufficiently-developed science and technology at that time, environmental problems were not seriously treated. Literature scholars and critics hope to solve the problem through the researches in philosophy and anthropology. Under this special background, eco-criticism was born. It is the manifestation of people's need for preventing and relieving eco-catastrophe in the form of literary criticism.

In 1991, Jonathan Bate, a professor in University of Liverpool, used this term in his newly published book. He called it "literary eco-criticism" (Bate, 1991, p. 11). Some scholars suggest that this book marks the advent of ecological literature research in the United Kingdom.

In America, the amount of courses related to ecological literature or relationship between literature and environment in universities and colleges has "dramatically increased in recent decades” (WANG, 2006, p. 21). A lot of graduate dissertations are about the nature and literature.

Eco-critics suggest that human's literature should be responsible for ecological crisis, because literature itself is one of the deep causes of ecological crisis. In some literary works, writers describe the large fortune people gained from the nature. This inspires people's idea of tapping natural resources. Literary writers and critics must remold literature and literary concept to stop crime against ecological environment and to atone for man's crime. Eco-critics have came to agreement that the mission of eco-criticism is to explore how human's 
thought, culture, science, life style, and social development mode influence or even determine man's bad attitude towards nature and thus lead to ecological crisis. The target of eco-criticism is a revolution in thought and culture, further in mode of production, science research, life style, and mode of development, finally a new civilization harmonious with nature.

\section{Ecological Consciousness}

The typical consciousness of ecologism includes Animal Welfare, Bio-centrism, and Eco-centrism.

Animal Welfare expanded the range of moral concern from human beings to other animals; it provided the theoretical foundation for the protection of animals' living rights. But Animal Welfare mainly concerned on interests and rights of some higher-level animals, and it rejected to think about lower-level animals, all the plants, and inanimate objects. So the theory was criticized by both the anthropocentrism and anti-anthropocentrism. Anthropocentrism suggested that Animal Welfare has excessively expanded its range, thereby more interests conflict came out. While anti-anthropocentrism suggested that Animal Welfare was too narrow and limited for it could not fight for the interests and rights of more natural objects.

Bio-centrism was more advanced than Animal Welfare for it no longer limited its objects in a narrow range, and it was against the idea of life level. Instead, it confirmed the equality of all things in the world. But Bio-centrism was not perfect. It did not pay attention to the intrinsic value of life community.

Based on the foundation of Bio-centrism, Eco-centrism enlarged and enriched the concept of value. It furthered the value from individuals to the whole ecological system. It valued both living organism and inanimate nature. Eco-centrism gave the new meaning to the nature and provided theoretical basis to overcome anthropocentrism.

After the formation of these basic patterns, ecological consciousness developed to its extreme pattern-Deep Ecology. Put forward by Arne Naess, Deep Ecology was one of the most radical theories in ecologism. Naess suggested that Deep Ecology focused on the interests of the whole nature while Shallow Ecology only cared about human's rights and interests. Shallow Ecology was anthropocentrism while Deep Ecology was anti-anthropocentrism. Shallow Ecology mainly focused on the symptoms of environmental degradation such as depletion of resources and pollution while Deep Ecology mainly discussed about the reasons of former problems occurred. Deep Ecology was about society, culture, and human nature. In practice, Shallow Ecology advocated improving the existing values and social system; Deep Ecology aimed to rebuild the rule of human civilization to make civilization as one part of the whole nature.

Deep Ecology attributed the origin of ecological problems to institutional and cultural crisis. Politically, Deep Ecology advocated the hierarchy, local autonomy, and decentralization. Economically, Deep Ecology supported the idea of replacing the living standard in industrial society by using the moderate quality of life to restrain material desire. The scheme of social transformation in Deep Ecology mainly focused on the change of individual's attitude. First, it asked individuals to change their minds, values, and life styles. Then, Deep Ecology suggested individuals to respect nature and exist with nature in a harmonious way. Thus Deep Ecology was an extreme theory related to extensive demands in political, economical, cultural, and social transformation.

Both of the meaning and influence of ecology are profound. The process of completing and developing the ecological theory shows how much effort scholars and researchers have devoted to ecology. Movements and 
activities related to ecology indicate that more and more people gradually pay their attention to the environment. Ecology has become a main theory and research object in the world.

\section{Formation of Jack London's Ecological Ideas}

\section{Historical Context}

Jack London lived in a period that people were not friendly to each other. Instead, the life was full of competition. Living in that horrible age, London witnessed the cruelty of society.

At that time, America was at the beginning of the industrial civilization. London's ecological consciousness was formed in that special age. With the rapid development of industrialization and mechanization, America transformed from a traditional agricultural country to an industrial country. Social wealth quickly accumulated with the economic growth. Lots of problems occurred in the process of industrial civilization. Those problems not only related to environment but also to human's spirits. In this case, battles for living became shockingly-cruel. People believed that work was the core of life. Working day and night, they gradually lost their vigor and vitality. They became the slaves of machines. After people completely became the slaves of life, things as love, friendship, and other pure relationship between people were gradually replaced by money, competition, and interests. Social polarization made people addict in money, thus they could hardly find inner peace.

Actually, in the industrial society, the spiritual crisis of human and ecological crisis of nature occurred in the same time. When environment was polluted, people's spirits also suffered from the civilization. When soil erosion, decrease of species, and exhaustion of resources changed the ecological environment, the loss of faith, integrity, and moral sense also changed the human beings.

With the booming of mechanization and industrialization, a mass of philosophical thoughts came out and contended with each other in the highly-civilized society. Jack London's thought was formed in this age. Influenced by theories and thoughts of Charles Robert Darwin, Herbert Spencer, Nietzsche, Marx, and Freud, London almost accepted all the ideas which had influence on the society at that time.

\section{Life Experience}

Jack London came from the bottom of the society. From about thirteen, he supported himself with some hard and dangerous jobs, experiencing the bitterness and cruelty of life. London was tired of competition and modern life after he saw too many tragedies in life. He was inspired to go to the wild to find his value and realize his dream. On July 12, 1897, London sailed to join the Klondike Gold Rush, where he saw life as a "struggle for existence in which quarter was always denied” (WANG \& LI, 2010, p. 208). It was a key and perilous time, detrimental to his health. He had found no gold and developed scurvy. He stopped his adventure and returned home earlier than he had planned. He came back home with little money, but had gained rich experiences from the wilderness and learnt some hard lessons from life. The abundant life experience enriched London's writing materials.

Jack London was a special writer with complicated ideology. "He was basically self-educated in natural law and determinism” (CHANG, 2003, p. 152). He read a large number of books written by Charles Darwin, Marx, and Nietzsche in public library. Influenced by these great scholars, London formed his creative ideas and writing style. 


\section{Eco-criticism in The Call of the Wild}

\section{The Disharmonious Relationship Between Human and Animals}

London expressed his resentment towards the society in most of his works. One of his novels-The Call of the Wild-is a typical work revealing his attitude. The Call of the Wild is London's best-known work and it was the first book that brought London the worldwide reputation.

The novel's leading character is a strong dog named Buck. This domesticated dog lives as the pet of a Judge when the story begins. Stolen from his home by the gardener, he is sold to several gold diggers. In order to dominate other dogs, Buck is forced to fight. Finally he sheds the veneer of civilization and learns experience to emerge as a leader in the wild. The main conflict in The Call of the Wild is the struggle between "civilization and the wild” (WANG \& LI, 2010, p. 211).

At the beginning of the story, Buck lived in Judge Miller's home happily. But after he was stolen and shipped to Seattle, his life changed. Buck was not a beloved pet anymore. Put in a crate, he was unfed and beaten by the "stout man with the red sweater" (London, 2009, p. 8). Buck's masters were quite greedy and self-indulgent. They did not have any respect for the dogs and often hit the dogs with no reason. Buck was set to work like a horse. "Francois fastened upon him an arrangement of straps and buckles” (London, 2009, p. 15). While “Dave, who was an experienced wheeler, nipped Buck’s hind quarter whenever he was in error" (London, 2009, p. 15). Maltreated by the cruel and brutal masters, Buck learned to submit to humiliation and bear their insult. The disharmonious relationship between human and dogs was described by London truthfully. Human's cruelty and selfishness was stated with no concealment.

McClinton suggested that London “combined romanticism and subjective character” (McClinton, 1997, p 382). This view was accepted and admitted by other scholars. As it was described in a Chinese scholar's work: "We can see the intention of romanticism in Jack London’s realism fictions" (YU, 2009, p. 137). After suffering from previous masters, Buck was saved by “an ideal master” (Pizer, 1995, p. 240)—John Thorton. John Thorton is a man who "saw to the welfare of his dogs as if they were his own children, because he could not help it" (LEI, 2012, p. 99). Thorton’s love makes Buck “slowly won back his strength” (London, 2009, p. 62) and grow stronger than ever. But unfortunately, Thorton was killed by several Indians. After revenge, Buck realized his nature and returned to the wild with a wolf he had met before. When he joined the wolf pack with his comrade, Buck was attacked by several wolfs while he was totally not afraid of them. He fought back and became the winner. Thus he was admitted as a real member of wolf pack and finally became the leader of the wolf pack. From then on, he lived the life he should have. The end of the story reflected London's longing for harmonious relationship between human and animals.

\section{The Disharmonious Relationship Between Human and Nature}

In eco-critical opinion, man is a member, while not the ruler. Human's existence and development depend on all the parts of the whole ecosystem. While in the society London lived in, human beings did not respect the law of nature. They thought they were the masters of the nature and they certainly had the rights to do anything they wanted to satisfy their desires. In order to gain more resources and interests, people did not hesitate to damage the environment. Their unlimited plunder broke the balance of the nature. Living in the unhealthy society with too many environmental problems, London craved for getting closer to nature. 
According to ecologism, all creatures and places in this world, favorable or unfavorable, beautiful or ugly, all together constitute the eco-system. Therefore, man cannot be separated from nature. In The Call of the Wild, the main settings are in the northern wilderness such as Yukon Territory and Alaska. These inaccessible areas are so brutally frigid and perilous that only the strongest creatures could survive. From ecological view, thought it is not suitable for man to live, wilderness has its own right to exist. Though the wilderness is primitive and ruthless, it is pure and fair. Wilderness treats all creatures equally without discrimination. Nobody has the privilege. All the creatures live in the same condition, so they should mutually respect each other, and together make great effort to overcome the difficulties.

At the beginning of The Call of the Wild, London described an ideal environment to live in. It described like this:

Buck lived at a big house in the sun-kissed Santa Clara Valley. Judge Miller's place, it was called. It stood back from the road, half hidden among the trees, through which glimpses could be caught of the wide cool veranda that ran around its four sides. The house was approached by graveled drive-ways which wound about through wide—spreading lawns and under the interlacing boughs of tall poplars. (LEI, 2012, p. 28)

The description of Judge Miller's house reveals London's desire that he prefers to live in country or a valley. Modern society places people in the contaminated air and narrow space. In London’s opinion, countryside, valley, and the entire wilderness become the symbols of freedom. Although the wilderness might be hard for people to survive, it still represents the purity and fairness. Many people reach Klondike and Alaska to find gold, but they hardly know the basic tips such as how to drive a sled. But dogs can easily adapt the cold weather and dangerous condition.

In the end of The Call of the Wild, Buck got rid of the civilization's bondage and returned to nature. He was accepted and admitted by wolf pack, and "he may be seen running at the head of the pack through the pale moonlight” (LEI, 2012, p. 130). He would never be hit or maltreated by human. In the nature, he could behave like a real dog and live with his own will. When he returned to nature, he was totally free. Nothing could limit him anymore.

\section{Conclusion}

This paper mainly explores Jack London's eco-critical ideas which revealed in his representative work-The Call of the Wild. First, the writer states the concept of ecological ideas especially the concept of eco-criticism. The elaboration of theoretical knowledge helps readers have a better understanding of eco-criticism. Then by introducing London's life experience and social situation in the age he lives in, readers can easily understand how and why Jack London becomes an ecologist. The following part analyzes several paragraphs in The Call of the Wild which can clearly reflect London's ecological ideas. In the end, the writer expresses the purpose of writing this thesis. It aims to appeal to people's attention of relationship between human and nature. By quote of disharmonious relationship and description of the dog's happy ending from The Call of the Wild, the paper also shows London's great hope of returning nature.

\section{References}

Barry, P. (2009). Beginning theory: An introduction to literary and cultural theory. Manchester: Manchester UP. 
Bate, J. (1991). Romantic ecology: Wordsworth and the environmental tradition. London: Routledge.

Buell, L. (2001). Writing for an endangered world: Literature, culture, and environment in the US and Beyond. Cambridge, MA and London, England: The Belknap Press of Harvard University Press.

CHANG, Y. X. (2003). A survey of American literature. Tianjin: Nankai University Press.

Donald, P. (1995). American realism and naturalism. New York: Cambridge University Press.

Donald, P. (2009). American realism and naturalism. Wuhan: Wuhan University Press.

Glotfelty, C., \& Fromm, H. (1996). The ecocriticism reader: Landmarks in literary ecology. Athens: The University of Georgia Press.

LEI, M. (2012). Selected stories of Jack London. Tianjin: Tianjin University Press.

London, J. (2009). The call of the wild/white fang. Beijing: Tsinghua University Press.

McClinton, J. (1997). Jack London's strong truth. Michigan: Michigan State University Press.

Pizer, D. (1995). American realism and naturalism. New York: Cambridge University Press.

WANG, N. (2006). Euro-American ecoliterature. Beijing: Beijing University Press.

WANG, Z., \& LI, Q. W. (2010). The history of American literature. Wuhan: Central China Normal University Press.

WEI, Q. Q. (2002). The study of the rising green literature-ecological criticism. Foreign Literature, 3, 34-38.

YU, J. H. (2009). The study of Jack London. Shanghai: Shanghai Foreign Language Education Press. 